\title{
Primary Intracranial Malignant Melanoma Mimicking Meningioma-Report of Two Cases
}

\author{
Laxmikant Bhople ${ }^{1}$ Hrushikesh U. Kharosekar ${ }^{1}$ Harish Naik ${ }^{1} \quad$ V. Velho ${ }^{1}$ \\ ${ }^{1}$ Department of Neurosurgery, Sir J J group of Hospitals and Grant \\ Address for correspondence Hrushikesh U. Kharosekar, MCh, \\ Medical College, Mumbai, Maharashtra, India \\ Department of Neurosurgery, 4th floor, Grant Medical College and \\ Sir J J Group of Hospitals, Byculla E, Mumbai 400008, Maharashtra, \\ India (e-mail: hkharosekar@gmail.com).
}

Indian J Neurosurg:2020;9:93-98

\begin{abstract}
Keywords

- primary malignant melanoma

- meningioma

- radiotherapy

- chemotherapy

Primary intracranial melanoma is uncommon and accounts for only approximately $1 \%$ of all cases of melanoma. This is interesting to neuro-oncologists and neurosurgeons because the clinical and radiological patterns of these tumors can mimic the presence of meningioma. Primary central nervous system melanomas have rarely been reported with less than 25 cases reported till date. We report two cases of the primary intracranial melanoma that even though very rare should be kept as a differential diagnosis when meningioma is suspected.
\end{abstract}

\section{Introduction}

Primary intracranial malignant melanoma (PIMM) is uncommon and accounts for only $~ 1 \%$ of all cases of melanoma. This is interesting to neuro-oncologists and neurosurgeons because the clinical and radiological patterns of these tumors can mimic the presence of meningioma. Since melanocytes are considered to originate from neural crest and are found in normal leptomeningeal tissue, it is not surprising that primary melanomas also grow within the central nervous system (CNS). ${ }^{1}$ Most patients with cerebral melanomas show clinical manifestation of increased intracerebral pressure (43\%), neurological dysfunctions (35\%), and convulsion or subarachnoid hemorrhage (16\%). Primary cerebral melanoma has a male dominance. Primary cerebral melanomas are not reported commonly. They can spread to other systems and organs and are aggressive in nature. It is commonly a diagnosis of exclusion solitary intracranial lesions with no melanomatous lesions found outside the CNS that could be primary melanomas. To achieve a desirable survival, the key treatment of choice for local intraparenchymal melanomas is complete resection plus radiochemotherapy. Temozolomide, as an effective chemotherapeutic medication, can cross blood-brain barriers and exert cytotoxic effects on cancer cells in patients with malignant melanoma. However, once cancer spreads to leptomeninges, the overall median survival is generally only 10 weeks. ${ }^{2}$

Primary CNS melanomas have rarely been reported with less than 25 reported till date. ${ }^{3}$ We report two cases of the primary intracranial melanoma, which we thought to be meningioma preoperatively, were found to be large melanomas (-Table $\mathbf{1}$ ). So even though very rare, PIMM should be kept as a differential diagnosis.

\section{Cases}

\section{Patient 1}

A 35-year-old female patient presented to us with complaints of headache, vomiting, and neck pain for the last 1 month. Her neurological examination was normal. Computed tomography (CT) scan revealed a well-defined, extra-axial, dural-based, hyperdense lesion measuring $33.53 .7 \mathrm{~cm}$ with homogenous enhancement. CT scans of the chest, abdomen, and pelvis showed no abnormalities. Magnetic resonance imaging (MRI) with contrast of the brain showed a lesion in the in left parietal area that was hyperintense on T1-weighted images and hypointense on T2-weighted images. There was heterogeneous enhancement after administration of gadolinium. Clinically and based on imaging characteristics, we published online

February 9, 2021
DOI https://doi.org/ $10.1055 / \mathrm{s}-0040-1714167$ ISSN $2277-954 X$.
(C) 2021. Neurological Surgeons' Society of India.

This is an open access article published by Thieme under the terms of the Creative Commons Attribution-NonDerivative-NonCommercial-License, permitting copying and reproduction so long as the original work is given appropriate credit. Contents may not be used for commercial purposes, or adapted, remixed, transformed or built upon. (https://creativecommons.org/licenses/by-nc-nd/4.0/)

Thieme Medical and Scientific Publishers Pvt. Ltd. A-12, 2nd Floor, Sector 2, Noida-201301 UP, India 
Table 1 Review of the cases reported in literature till date ${ }^{3,6}$

\begin{tabular}{|c|c|c|c|c|c|}
\hline $\begin{array}{l}\text { Case } \\
\text { no. }\end{array}$ & Authors & Age/sex & Site & Treatment & Survival/follow-up \\
\hline 1 & $\begin{array}{l}\text { Nakagawa } \\
\text { et al, } 1989\end{array}$ & $\begin{array}{l}57 \\
\text { Male }\end{array}$ & Intracranial & $\begin{array}{l}\text { Excision, chemoimmunoradiotherapy, } \\
\text { chemoradiotherapy }\end{array}$ & Died after 9.6 years \\
\hline 2 & $\begin{array}{l}\text { Braga et al, } \\
1989\end{array}$ & $\begin{array}{l}72 \\
\text { Female }\end{array}$ & CP angle & Total excision & $\begin{array}{l}\text { Died on 5th postoperative } \\
\text { day }\end{array}$ \\
\hline 3 & $\begin{array}{l}\text { lizuka et al, } \\
1990\end{array}$ & $\begin{array}{l}76 \\
\text { Male }\end{array}$ & Occipital & Total excision & 1-year follow-up, alive \\
\hline 4. & $\begin{array}{l}\text { Takano et al, } \\
1992\end{array}$ & $\begin{array}{l}34 \\
\text { Male }\end{array}$ & Intracranial & Chemotherapy, interferon- $\beta$ & NA \\
\hline 5 & Lee et al, 2004 & $\begin{array}{l}66 \\
\text { Male }\end{array}$ & $\begin{array}{l}\text { Left frontoparietal } \\
\text { region }\end{array}$ & Total excision & Died after 6 months \\
\hline 6. & $\begin{array}{l}\text { Önal et al, } \\
2006\end{array}$ & $\begin{array}{l}38 \\
\text { Male }\end{array}$ & $\begin{array}{l}\text { Posterior fossa mass } \\
\text { Recurring left tem- } \\
\text { poro-occipitoparietal }\end{array}$ & $\begin{array}{l}\text { Excision, adjuvant, external beam } \\
\text { irradiation, } \\
\text { chemotherapy, and interferon } \\
\text { chemotherapy }\end{array}$ & 17 years \\
\hline 7 & $\begin{array}{l}\text { Bhandari et al, } \\
2010\end{array}$ & $\begin{array}{l}29 \\
\text { Male }\end{array}$ & CP angle & $\begin{array}{l}\text { Subtotal excision with adjuvant } \\
\text { radiotherapy }\end{array}$ & Died after 1 year \\
\hline 8 & $\begin{array}{l}\text { Azar et al, } \\
2010\end{array}$ & $\begin{array}{l}21 \\
\text { Male }\end{array}$ & Parietal & $\begin{array}{l}\text { Total excision, radiotherapy and } \\
\text { chemotherapy }\end{array}$ & 1-year follow-up, alive \\
\hline 9. & $\begin{array}{l}\text { Shah et al, } \\
2012\end{array}$ & $\begin{array}{l}28 \\
\text { Female }\end{array}$ & Left temporal lobe & Excision of mass & 4 years, alive \\
\hline 10 & $\begin{array}{l}\text { Mahajan et al, } \\
2013\end{array}$ & $\begin{array}{l}55 \\
\text { Female }\end{array}$ & Clivus & $\begin{array}{l}\text { Palliative chemotherapy and brain } \\
\text { irradiation }\end{array}$ & NA \\
\hline 11 & $\begin{array}{l}\text { Ponni et al, } \\
2014\end{array}$ & $\begin{array}{l}38 \\
\text { Male }\end{array}$ & Left CP angle & $\begin{array}{l}\text { Total resection, adjuvant, radiation and } \\
\text { chemotherapy }\end{array}$ & 1-year follow-up, alive \\
\hline 12 & $\begin{array}{l}\text { Wang et al, } \\
2014\end{array}$ & 8 patients & Intracranial & $\begin{array}{l}\text { Total excision-6 } \\
\text { Subtotal excision-2 } \\
\text { Radiotherapy-6 }\end{array}$ & $\begin{array}{l}\text { 13.8-month follow-up: } \\
3 \text { died, } 5 \text { alive }\end{array}$ \\
\hline 13 & $\begin{array}{l}\text { Suranagi et al, } \\
2014\end{array}$ & $\begin{array}{l}65 \\
\text { Male }\end{array}$ & $\begin{array}{l}\text { Right parafalcine } \\
\text { frontal region }\end{array}$ & Total excision & 1-year follow-up, alive \\
\hline 14 & Our series & 2 patients & $\begin{array}{l}\text { Intracranial, } \\
\text { supratentorial }\end{array}$ & Total excision & $\begin{array}{l}1 \text { st patient died after } \\
2 \text { years } \\
2 \text { nd patient alive at } \\
3 \text { months }\end{array}$ \\
\hline
\end{tabular}

Abbreviations: CP, cerebellopontine; NA, not available.

suspected hemorrhagic metastasis or a meningioma with intratumoral bleeding (-Fig. 1).

Intraoperatively, a large blackish, vascular, firm mass measuring was seen in left parietal area extending up to temporal lobe along sylvian fissure with brain dark black discolouration of brain. There was well-defined tumor-brain interface enabling near complete excision of the lesion. Postoperative scan showed complete excision of the lesion (-Fig. 1). Cerebrospinal fluid examination showed no evidence of atypical or malignant cells.

\section{Patient 2}

A 42-year-old male patient presented to us with complaints of headache and one episode of generalized tonic-clonic seizure. Neurological examination was normal. CT scan revealed a right-sided large well-defined, multilobulated, extra-axial, dural-based lesion measuring $75.55 \mathrm{~cm}$ with heterogenous enhancement on contrast. CT scans of the chest, abdomen, and pelvis showed no abnormalities. MRI with contrast of the brain showed a large lesion in the in right temporoparietal region that was hyperintense on T1-weighted images and hypointense on T2-weighted images. There was heterogeneous enhancement after administration of gadolinium with significant perilesional edema. Clinically and based on imaging characteristics, we suspected malignant meningioma (-Fig. 2).

Intraoperatively, a large blackish, vascular, firm mass was seen in right parietal area extending up to temporal lobe along sylvian fissure with thin layer of brain parenchyma covering it. There was well-defined tumor-brain interface enabling near complete excision of the lesion. There was invasion of dura as well as bone, showing black discoloration. Postoperative scan showed complete excision of the lesion (-Fig. 3). Cerebrospinal fluid examination showed no evidence of atypical or malignant cells.

Histopathological examination in both cases revealed a neoplasm arranged in nests and diffuse sheets. Individual tumor cells were epithelioid shaped, showing a moderate amount of eosinophilic cytoplasm with round to oval pleomorphic nucleus having prominent nucleoli in majority of 


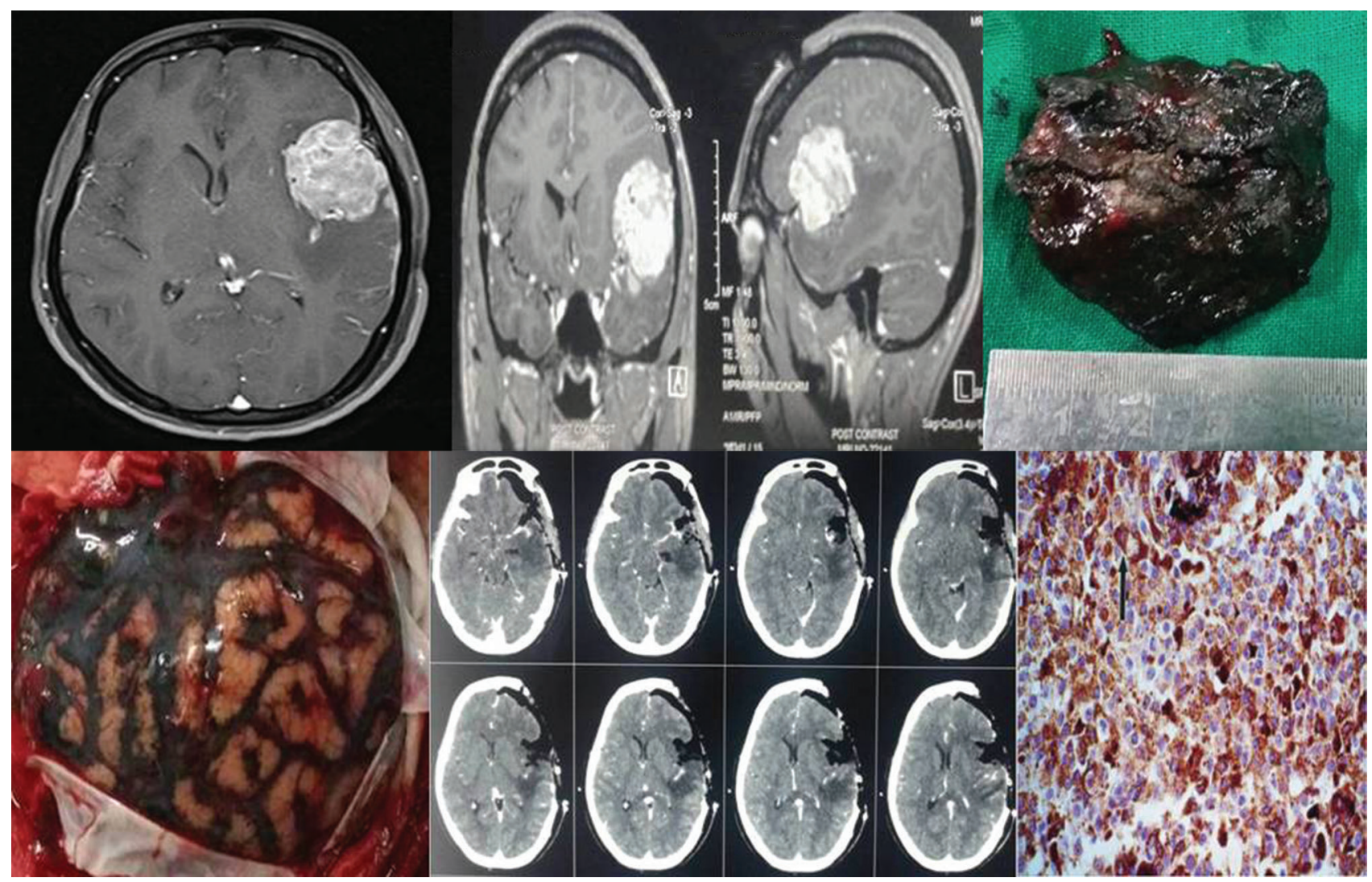

Fig. 1 Images of case 1 showing preoperative magnetic resonance imaging brain with contrast, intraoperative lesion and histopathology slide.

cells. Multinucleation was evident along with mitotic activity. There was extensive intracellular as well as extracellular brownish black melanin pigment s/o malignant melanoma. Dopa oxidase reaction was positive. The tumor cells exhibited positivity for HMB-45, S-100, and vimentin (-Fig. 3). In view of strong clinical suspicion of metastasis and rarity of primary malignant melanoma, a search for primary lesion was made. A thorough examination of her skin showed no abnormal pigmentation or texture and fundoscopy of both eyes revealed normal retinae. Per rectal examination and colonoscopy were insignificant. CT scans of thorax, abdomen, and pelvis were also normal. The pathologic findings, together with the negative dermatologic, gastrointestinal, and ophthalmologic examinations, suggested a PIMM. Both patients were discharged and advised chemoradiotherapy.

\section{Discussion}

Primary melanoma of the CNS arises from melanocytes, which are derived from precursor cells (melanoblasts) originating in the neural crest. In the craniospinal axis, melanocytes are predominantly located in the leptomeninges at the anterior and lateral surfaces of the spinal cord, the brain stem, and the base of the brain. This distribution of melanocytes closely correlates with the reported distribution of these rare tumors. Females are affected twice as common as males. ${ }^{1,4}$

Differentiating whether a melanocytic tumor is primary or metastatic in origin can be difficult. According to criteria set forth by Hayward, CNS melanoma is more likely to be primary if there is no evidence of melanoma outside the CNS. The presence of leptomeningeal involvement, intramedullary spinal lesions, hydrocephalus, pineal region tumors, or a solitary brain lesion also suggests a CNS origin. Our patient had a solitary lesion with leptomeningeal involvement, also no systemic disease. ${ }^{5}$

Since systemic melanomas frequently metastasize to the CNS, a definitive diagnosis of primary CNS melanoma can be made if no systemic focus considered to be primary is found. Terao et al reported clinical differences between metastatic and primary melanomas in the CNS. Metastatic melanomas are characterized by (1) multiple intracerebral tumors, (2) a rapid and poor clinical course due to systemic metastases, and (3) older age group.

Regarding primary melanoma of the nervous system, the origin of melanin cells is not fully understood, although several histogenetic theories have been proposed: (1) the mesodermal theory: the mesoderm gives rise to pigment cells that reach the brain or spinal cord via the pial blood vessels; (2) the ectodermal theory: some epithelial cells produce pigment, and therefore CNS melanomas are derived from the aberrant embryonic ectodermal cells; (3) the neurogenic theory: the pigment cells originate from the neural crest, which develop into mesodermal and neural elements. ${ }^{1}$

Primary melanoma of the CNS can be divided into four different categories of pigmented lesions with pathological sequelae: (1) diffuse leptomeningeal melanomatosis that infiltrates leptomeninges of the brain and spinal cord, (2) discrete spinal cord 


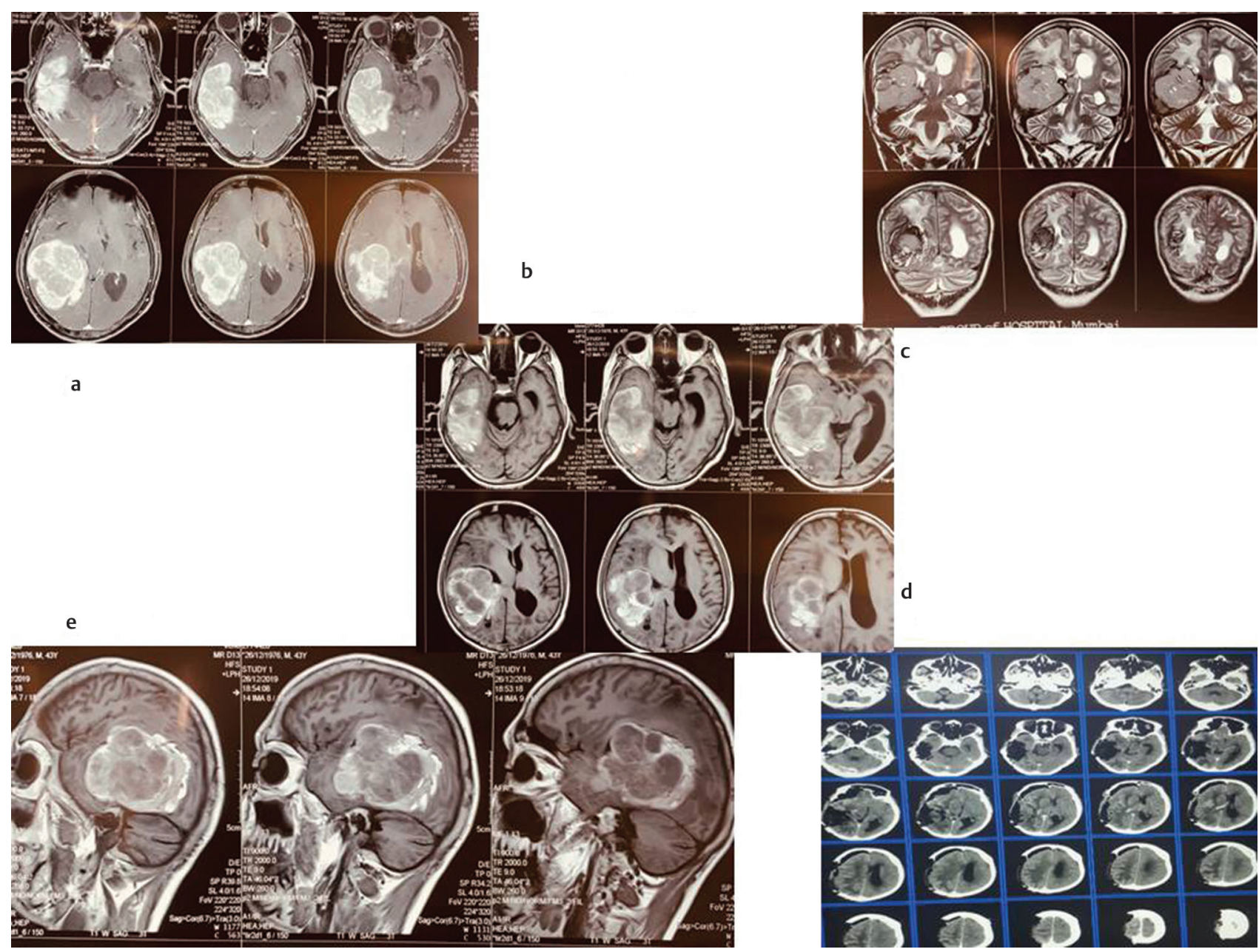

Fig. 2 Images of case 2 showing preoperative magnetic resonance imaging brain with contrast and postoperative computed tomography scan of brain with complete excision of lesion. (A) Preoperative MRI of the brain, T1 contrast image showing the lesion. (B)Preoperative MRI of the brain, T1 weighted image showing the lesion. (C) Preoperative MRI of the brain, T2 flair sequence. (D) Preoperative CT scan with contrast showing complete excision of lesion. (E) Preoperative MRI of the brain, saggital sections.

melanomas, (3) primary intracranial isolated melanomas, and (4) melanosis of the meninges of the brain and/or the spinal cord associated with cutaneous pigmentation (so-called neurocutaneous melanosis or phakomatosis). Their clinical manifestations are similar to other neoplasms of the cerebrum. The MRI findings depend on the type of melanoma and the presence or absence of intratumoral hemorrhage. ${ }^{1}$ Histologically, melanocytoma is a benign lesion without any invasion, while malignant melanomas are invasive with increased proliferation index ( - Table 2).

Radiotherapy, chemotherapy, and immunotherapy may be considered nonsurgical therapy options for primary melanoma of the CNS, but their effects have not been clearly established.
Olli-Pekka et al suggested that higher total doses of radiation (>40 Gy) should be irradiated to the tumor area for patients with good general conditions and absence of controlled extracranial disease. As for chemotherapy, dimethyl-triazeno-imidazole-carboxamide) is the most commonly employed chemotherapeutic agent. ${ }^{1}$

\section{Conclusion}

CNS melanoma without any cutaneous manifestations is difficult to diagnose preoperatively. The clinical and radiological findings are the most important clues in the diagnosis, but it is a diagnostic dilemma. The prognosis is quite good in cases 

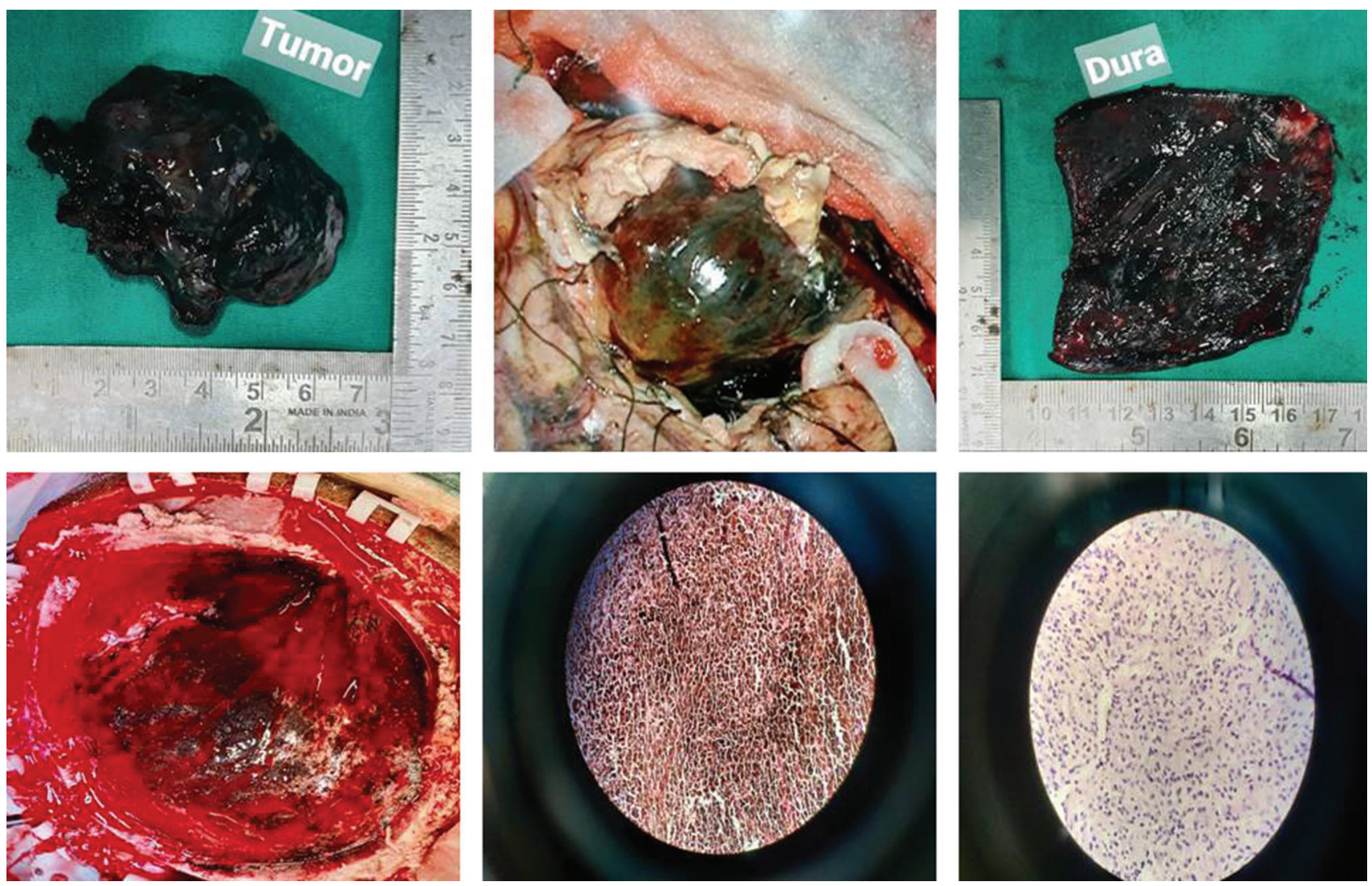

Fig. 3 Intraoperative images of case 2 with histopathology slides.

Table 2 Histopathological difference between melanocytoma and malignant melanoma

Microscopic (histologic) description

Melanocytoma:

- Solitary, circumscribed lesions-do not invade adjacent structures

- Solitary, circumscribed lesions-do not invade adjacent structures

- Nests (reminiscent of whorls) of relatively uniform cells with variable melanin pigment

- Nests (reminiscent of whorls) of relatively uniform cells with variable melanin pigment

- Bland, oval nuclei with eosinophilic nucleoli

- Bland, oval nuclei with eosinophilic nucleoli

- Mitoses no more than 1/10 HPF

- Mitoses no more than 1/10 HPF

Malignant melanoma:

- Hypercellular sheets or nests of spindled or epithelioid cells

- Hypercellular sheets or nests of spindled or epithelioid cells

- May have significant pleomorphism

- May have significant pleomorphism

- Atypical mitoses (5/10 HPF)

- Atypical mitoses (5/10 HPF)

- Invasion of adjacent structures or necrosis may be seen

- Invasion of adjacent structures or necrosis may be seen

- Prominent nucleoli

- Prominent nucleoli

Abbreviation: HPF, high power field. 
of totally excised melanomas. So, aggressive surgical resection is recommended. The role of adjuvant therapy is not well known.

Conflict of Interest

None declared.

\section{References}

1 Liao W-C, Ho J-T, Lai1 P-H, Tseng H-H. Primary intracranial melanoma: report of a case and review of the literature. Mid Taiwan J Med 2002;7:118-123

2 Tang K, Kong X, Mao G, et al. Primary cerebral malignant melanoma:acase report with literature review.Medicine(Baltimore) 2017;96(4):e580510.1097/MD.0000000000005805
3 Suranagi VV, Maste P, Malur PR. Primary intracranial malignant melanoma: a rare case with review of literature. Asian J Neurosurg 2015;10(1):39-41

4 Shah I, Imran M, Akram R, Rafat S, Zia K, Emaduddin M. Primary intracranial malignant melanoma. J Coll Physicians Surg Pak 2013;23(2):157-159

5 Somers KE, Almast J, Biemiller RA, Silberstein HJ, Johnson MD, Mohile NA. Diagnosis of primary CNS melanoma with neuroimaging. J Clin Oncol 2013;31(1):e9-e11

6 Naik H, Kharosekar H, Velho V. Black brain caused by primary intracranial malignant melanoma. Neurol India 2016;64(1):193-194 